Scientific Journal Warsaw University of Life Sciences - SGGW

Problems of World Agriculture volume 17 (XXXII), number 4, 2017: 21-30

DOI: $10.22630 /$ PRS.2017.17.4.78

Urszula Bronisz ${ }^{1}$, Andrzej Jakubowski ${ }^{2}$

Maria Curie-Sklodowska University in Lublin

\title{
Rural Tourism as a Factor Stimulating the Development of Border Areas - The Case of Lubelskie Voivodeship
}

\begin{abstract}
This article aims to evaluate the level of tourism potential for the communities located in the eastern border region of the Lubelskie Voivodeship in Poland. The analysis was based on a threefactor model consisting of separate interrelated components of tourism potential i.e. tourist attractiveness, tourist function and tourist traffic. Using a multidimensional comparative analysis, a Tourist Attractiveness Index, Tourist Function Index and Tourist Traffic Index were composed. This enabled to identify the territorial units for which rural tourism can become a real factor stimulating socio-economic development. It appears that rural tourism can be perceived as a chance for improving the local economy for the areas located in the northern part of the borderland, whereas for communities situated in the southern part, it is not a significant issue.
\end{abstract}

Key words: rural tourism, border areas, Lubelskie Voivodeship, Poland

JEL Classification: R110, R120

\section{Introduction}

The Lubelskie Voivodeship is a typical agricultural area characterized by a relatively low level of industrialization and urbanization. The eastern part of Lubelskie is a border region of Poland and also for the entire European Union. From the point of view of development opportunities this specific position is more a restrictive factor than an advantage. The territorial areas situated along the external border of the EU are less developed and poorly equipped with infrastructure. Their unfavorable location reduces the chances of improving their economic performance and living standards. Therefore peripheral, rural areas need a new approach in their development policy. In the process of transforming rural spaces, tourism can play an important role. Tourism is considered to be an effective catalyst for rural development (Sharpley and Vass, 2006), an important economic factor and an opportunity for creating non-agricultural businesses and jobs. It is widely acknowledged that tourism is not only one of the forms of human activity but also an important social and economic phenomenon in the contemporary world. Its development is related to the wide impact of tourism on many spheres of the national economy. As a significant economic phenomenon it is perceived by local and regional authorities as an opportunity for their development. However, the scale of economic benefits associated with the development of tourism is determined by a set of factors, i.e. natural and cultural values and attractiveness, good accessibility of transportation, and the development level of tourist infrastructure.

\footnotetext{
${ }^{1} \mathrm{PhD}$, Department of Socio-Economic Geography, Faculty of Earth Sciences and Spatial Management, Maria Curie-Sklodowska University in Lublin, al. Kraśnicka 2cd, e-mail: u-bronisz@o2.pl

${ }^{2} \mathrm{PhD}$, Department of Socio-Economic Geography, Faculty of Earth Sciences and Spatial Management, Maria Curie-Sklodowska University in Lublin, al. Kraśnicka 2cd, e-mail: andrzej.jakubowski@umcs.pl
} 
The aim of the paper is to assess the level of tourism potential for the territorial areas located in the eastern border region of the Lubelskie Voivodeship. Another objective of the study is to identify communities with relatively well-developed tourism functions. This will show the areas for which rural tourism can become a real factor stimulating their development. The structure of the article is as follows: The first section outlines a literature review concerning the notions of rural border areas and rural tourism. The next part provides the research framework of the paper. The following section focuses on the results obtained from the conducted analysis. Finally, the last section contains the conclusions.

\section{The Literature Review}

The development of rural border areas is determined by many different factors. Border areas, due to their geographical position, are often marginalized. Numerous studies have confirmed that rural areas remote form urban centres are characterized by lower levels of development and competitiveness (Rosner, 1999; Brodziński, 2011) and they usually suffer from economic disparities, high unemployment, depopulation and unfavorable demographic structure.

The development of rural border areas is influenced by a set of factors like the structure of the economy, the regional labour market or local government policy. In the process of modifying rural communities in their environmental, economic, social and cultural structures and development an important role is played by tourism (Theodoropoulou, Kaldis, 2008; Andereck et al., 2005, Briedenhann and Wickens, 2004). Rural tourism is a multi-faceted concept and has no commonly used definition in literature. This notion can be used as a geographical term as well as a term describing cultural activities of rural communities (Lane 1994). Most authors emphasize certain features of this phenomena, i.e. the rural character of the recreation, contact to nature, experience of heritage and participation in rural traditions (Lane, 1994; WTO 2004; Drzewiecki, 2002; Dębniewska, Tkaczuk, 2007). In broader terms rural tourism is understood as all tourismrelated activities that take place outside of urban areas and involve the natural and cultural patrimony of rural territories in promoting processes of local development. It includes low intensity activities that do not interfere significantly with the environment (Majewski, 1998; Tolstad, 2014). There are three main types of rural tourism, i.e. rural tourism covering all forms of recreation in the non-urbanized area, agricultural tourism - providing an opportunity to learn the practical aspects of a farmer's work - and rural tourism offering both theoretical and practical knowledge of the local community culture (Spychalski, 1998). They all are sub-components of tourism in rural space. Rural tourism can be one of the key factors contributing to the activation of a multifunctional development of a given area. The development of tourist functions can lead to the creation of new jobs and the diversification of income sources, as well as to the restoration of other sectors of the economy, i.e. trade or transport. Although rural tourism is generally addressed to individual travelers, families or small groups, it is regarded as an important element of diversification of the economic activity and at the same time as an alternative source of development (Majewski, Lane, 2003; Holland, Burian, Dixey, 2003).

The European Union (2002) has highlighted 10 factors that have a significant impact on the development of tourism in non-traditional tourist destinations, including rural areas, such as: natural and cultural values, distinctive features of the surrounding area, tourist 
attractions, branding, networking, transport accessibility, partnership, development strategy and protection of monuments. These are the most important factors that enable the transition of tourism potential into tourism function.

\section{Data and Methodology}

The area of interest for research is located in the eastern part of the Lubelskie Voivodeship, covering rural communities of Polish-Belarusian and Polish-Ukrainian border areas. Delimitation of the study area was carried out in two stages. In the first stage, the rural areas of the Lubelskie Voivodeship were isolated on the basis of the classification of the European Commission called DEGURBA (Eurostat, 2017). In the second stage, rural communities located in the border area were separated on the basis of the delimitation criteria applied in the Lublin Spatial Development Plan (UMWL, 2015). Finally, the survey covered 58 border municipalities of Lubelskie Voivodeship from 213 communities in total and 190 rural communities in the voivodship according to DEGURBA classification.

Empirical analyses were based primarily on statistical data provided by the Central Statistical Office of Poland for 2015. In addition, data from the Marshal Office of the Lubelskie Voivodship, the National Institute of Heritage, Center for Geodetic and Cartographic Documentation as well as the National Sanitary Inspection were used.

The presented analysis was based on a Three-factor model of a comprehensive assessment of the tourist potential of the Lublin Voivodeship (Bronisz et al., 2017). The model (Figure 1) includes three interrelated components of the tourism potential: tourist attractiveness (conditions), tourist function (outlay) and tourist traffic (effects). The natural and cultural attractiveness of the area are the basis for the development of the tourist function of the individual communities. Outlays for the development of the broadly understood tourist economy, being a potential source of income for a given local community, are expressed in the municipal tourist policy (budgetary income and expenditure of communities) and the existing tourist supply (tourist base and economic activity). Finally, the effects presented by the tourist demand (the size and structure of the tourism movement) show which of the analysed communities constitute the target area for tourist flows. The development of the tourism potential of the area and the economic benefits of the tourist economy are conditioned by the combined occurrence of the above-mentioned factors.

\begin{tabular}{|c|c|}
\hline \multicolumn{2}{|c|}{ Tourist Attractiveness (Conditions) } \\
\hline natural attractiveness & cultural attractiveness \\
\hline Tourist Function (Outlays) \\
\hline tourist policy \\
\hline \\
\hline
\end{tabular}

Fig. 1. The Three-factor model of a comprehensive assessment of tourist potential Source: Authors' own elaboration. 
According to the presented model, the following synthetic indicators were calculated for all communities of the Lubelskie Voivodeship:

- Tourist Attractiveness Index (TAI);

- Tourist Function Index (TFI);

- $\quad$ Tourist Traffic Index (TTI).

Each of the aforementioned indexes was based on a set of key indicators (Table 1). Due to the varied importance of the selected indicators, for each of them weight has been assigned. For this purpose, an expert method was applied. For the calculation of synthetic indicators, the method of relative distance from the pattern was used (multidimensional comparative analysis), which takes into account the nature of the indicator (stimulant or destimulant). For stimulants, formula (1) was used, and for destimulants - formula (2).

$$
\begin{aligned}
& H_{i j}=\frac{100\left(x_{i j}-x_{i \min }\right)}{x_{i \max }-x_{i \min }} \\
& H_{i j}=\frac{100\left(x_{i \max }-x_{i j}\right)}{x_{i \max }-x_{i \min }}
\end{aligned}
$$

where: $x_{i j}$ - empirical value of $i$-th measure in $j$-th municipality; $x_{i m i n}$ - lowest value of $i$-th meter among voivodeship communities; $x_{\text {imax }}$ - highest value of $i$-th meter among voivodeship communities.

Lubelskie Voivodeship was used (CODGiK, 2017). The surface water index was calculated as the share of land under surface waters flowing and standing in the area of the community. The forest index was calculated as the share of forests (area of forest land) in the total area of the community.

The other measures used to assess the attractiveness of the Lubelskie Voivodeship are the synthetic indicators. The synthetic index of protected areas was based on the weighted share of selected legal forms of nature conservation in the area of individual municipalities. According to G. Bezkowska (2003), the following weight factors were used in the study: national park -4 , nature reserve -3 , landscape park -2 , protected landscape area -1 . Thus the synthetic index of protected areas takes the following formula (3):

$$
I=A_{1} \cdot W_{1}+A_{2} \cdot W_{2}+\ldots+A_{n} \cdot W_{n}
$$

where: $A$ - relative surface area of each form of the nature conservation; $W$ - weight factor. The synthetic natural attraction index was based on the data concerning: nature monuments (per 1 sq.km), botanical and zoological gardens, watering places and health resorts. The individual elementary indices composing the synthetic natural attraction index were calculated according to the following formula (Łysoń, Szymkowiak, Wawrowski, 2016):

$$
I=\frac{100 \cdot x_{i}}{x_{i \max }}
$$

where: $x_{i}$ - empirical value for $j$-th community; $x_{\text {imax }}$ - highest value of $i$-th meter among voivodeship communities. A synthetic indicator of environmental status, data on emissions of dust pollution per year in tonnes per 1 sq.km, gas emissions per year in tonnes per 1 sq.km, the share of the population using waste water treatment plants and the mixed waste 
collected during the year were used. This indicator serves to assess the pollution of the natural environment as a factor limiting the tourist attractiveness of the analysed area.

Table 1. List of indicators used in the study

\begin{tabular}{|c|c|c|}
\hline Index & $\begin{array}{l}\text { Stimulant } \\
\text { destimulant }\end{array}$ & $\begin{array}{l}\text { Wage } \\
(\%)\end{array}$ \\
\hline \multicolumn{3}{|l|}{ Tourist Attractiveness Index (TAI) } \\
\hline \multicolumn{3}{|l|}{ Natural attractiveness: } \\
\hline The terrain index & stimulant & 7,5 \\
\hline The surface water index & stimulant & 7,5 \\
\hline The forest index & stimulant & 7,5 \\
\hline The synthetic index of protected areas & stimulant & 15 \\
\hline Synthetic natural attraction index & stimulant & 7,5 \\
\hline Synthetic indicator of environmental status & stimulant & 5 \\
\hline \multicolumn{3}{|l|}{ Cultural attractiveness } \\
\hline Synthetic index of historical monuments & stimulant & 12,5 \\
\hline The synthetic indicator of museum, stage and exhibition activities & stimulant & 12,5 \\
\hline Synthetic indicator of cultural events & stimulant & 12,5 \\
\hline The index of religious tourism & stimulant & 5 \\
\hline \multicolumn{3}{|l|}{ Tourist Function Index (TFI) } \\
\hline \multicolumn{3}{|l|}{ Tourist policy } \\
\hline Share of industrial land in built-up and urbanised land in 2014 (\%) & destimulant & 5 \\
\hline $\begin{array}{l}\text { Expenditures of the municipality per capita on the protection of atmospheric } \\
\text { air and climate }\end{array}$ & stimulant & 5 \\
\hline Expenditure of the municipality per capita on tourism & stimulant & 12,5 \\
\hline $\begin{array}{l}\text { Expenditure of the municipality per capita on the culture and protection of the } \\
\text { national heritage }\end{array}$ & stimulant & 12,5 \\
\hline $\begin{array}{l}\text { The income of the municipality from the culture and the protection of the } \\
\text { national heritage per 1,000 population (Section 921) }\end{array}$ & stimulant & 5 \\
\hline $\begin{array}{l}\text { The value of European projects (2004-2013) concerning tourism per 1,000 } \\
\text { inhabitants }\end{array}$ & stimulant & 10 \\
\hline \multicolumn{3}{|l|}{ Tourist demand } \\
\hline Bed places per 1000 inhabitants & stimulant & 10 \\
\hline Tourist Accommodation Establishments per 1,000 inhabitants & stimulant & 10 \\
\hline Agritourist Accommodation Establishments per 1,000 inhabitants & stimulant & 10 \\
\hline Companies per 1000 inhabitants - Section H, Division 49 & stimulant & 2,5 \\
\hline Companies per 1000 inhabitants - Section I & stimulant & 5 \\
\hline Companies per 1000 inhabitants - Section N, Division 79 & stimulant & 5 \\
\hline Companies per 1000 inhabitants - Section R & stimulant & 2,5 \\
\hline Share of recreation areas in built-up and urbanised areas in 2014 (\%) & stimulant & 5 \\
\hline \multicolumn{3}{|l|}{$\begin{array}{l}\text { Tourist Traffic Index (TTI) } \\
\end{array}$} \\
\hline Tourists per 1,000 inhabitants & stimulant & 25 \\
\hline Overnight stays per 1,000 inhabitants & stimulant & 25 \\
\hline Overnight stays (foreign tourists) per 1,000 inhabitants & stimulant & 20 \\
\hline Occupancy rate $(\%)$ & stimulant & 10 \\
\hline Museum visitors per 1,000 inhabitants & stimulant & 10 \\
\hline Participants of events per 1,000 inhabitants & stimulant & 10 \\
\hline
\end{tabular}

Source: Authors' own elaboration. 
The terrain index was calculated as the difference between the maximum and minimum height n.p.m. municipalities. In the study, the dataset of a numerical model of terrain for the

Data on the number of immovable monuments and archaeological sites by category per 1 sq.km of the area were used for the construction of the synthetic index of historical monuments. The following weight factors were used in this study: sets of monuments and castles -2 , urban layouts, sacred objects, residential buildings, public buildings -1 , other objects (defence buildings, dwellings, outbuildings and industrial objects, small architecture and archaeological monuments) - 0.5. Assuming the above weights, the synthetic indicator of historical monuments for individual municipalities takes the form expressed by the formula (5):

$$
I=A_{1} \cdot W_{1}+A_{2} \cdot W_{2}+\ldots+A_{n} \cdot W_{n}
$$

where: $A$ - number of monuments by the category; $W$ - weight factor.

The synthetic indicator of museum, stage and exhibition activities was built on four variables: exhibition venues, galleries and art galleries; museums; theatres and musical institutions. Data on the number of cultural events and mass events per 1,000 population were used to build the synthetic indicator of cultural events. Finally, the index of religious tourism was based on the number of sanctuaries. The three above-mentioned indicators were calculated according to formula (4).

In the next stage of the research rural communities of the Lubelskie Voivodship were classified into 4 categories within each of the analysed components according to all developed synthetic indicators (TAI, TFI, TTI). The division into two subsets was made on the basis of the mean, then the division of the two subsets into two parts (four in total) was made on the basis of the mean for the objects in both subsets. Depending on the value of the synthetic indicator, the rural communities located in the eastern part of the Lubelskie Voivodeship were assigned to group A - that consists of the communities with the highest indicator values, group B characterised by a relatively high level of the indicator, group $\mathrm{C}$ - with moderate index level or group $\mathrm{D}$ - grouping the units with the lowest values of the indicator.

The last stage of the research concerned the identification of the potentially attractive municipalities for the development of tourist function. For this purpose analysed territorial units were divided into four categories according to the level of tourist attractiveness (high or low TAI-value) and the level of tourist function development (high or low TFI-value). For this purpose, both variables were standardised according to the following formula (6):

$$
x=\frac{x_{i}-\bar{x}}{\sigma}
$$

where: $x_{i}$ - variable not standardised; $\bar{x}$ - arithmetic mean of the population; $\sigma-$ standard deviation of the population.

\section{Results}

According to the results of the conducted analysis, there are 5 rural communities in the border area of Lubelskie Voivodeship, characterized by the highest TAI values, 19 - with 
high, 17 - moderate and 17 - with low value of the indicator. In the top head of the TFI we can find 6 communes, almost all situated in the northern part of the borderland. These are the territorial units that have the most developed services for tourists. Among the examined group of the 58 communes, 13 achieved high scores, 22 - moderate results and 17 - poor performance. Spatial distribution of the obtained results was presented in Figure 2.

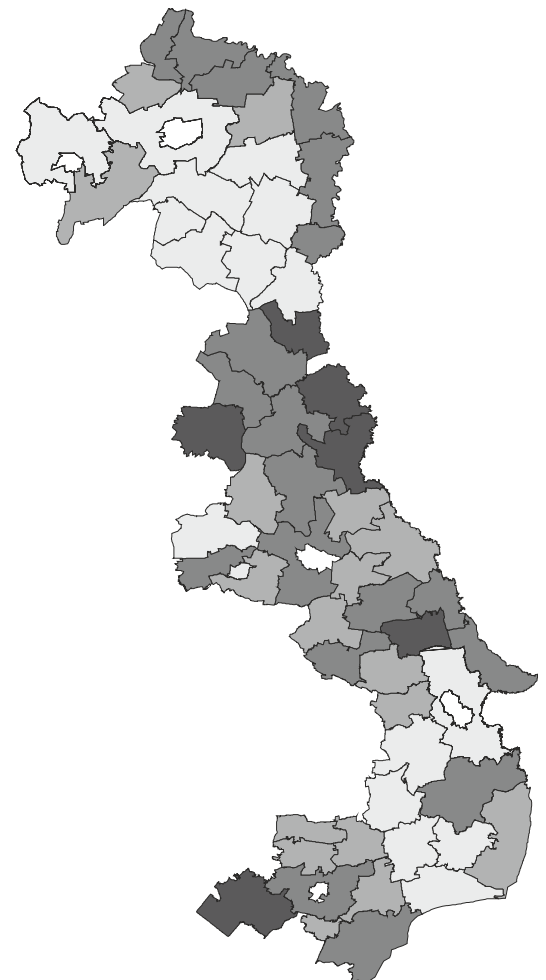

Tourist Attractiveness Index (TAI)

very high $(18,4$ and over $)$

high $(13,5-18,4)$

moderate $(10,3-13,5)$

low (less than 10,3)

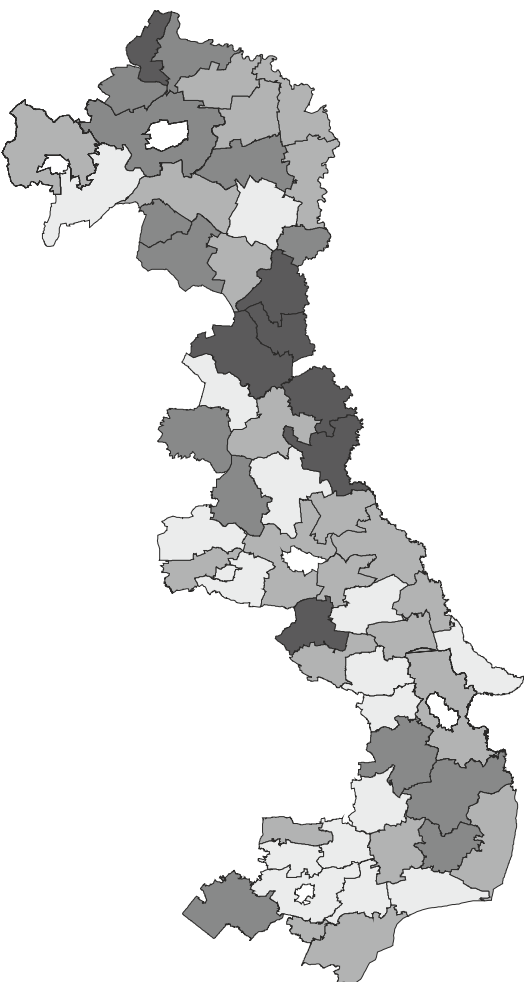

Tourist Function Index (TFI):

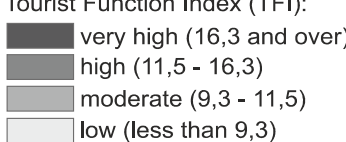

Fig. 2. Spatial distribution of the Tourist Attractiveness Index (TAI) and Tourist Function Index (TFI)

Source: Authors' own elaboration.

Both of the indicators discussed above were used to evaluate rural communities located in the border areas of the Lubelskie Voivodeship in terms of the tourist attractiveness utilisation for the purposes of tourist function development. As a result of the classification, four categories of municipalities were distinguished (Fig. 3):

- Category 1 (High-High) - encompassing 9 communities with high level of tourist attractiveness and high level of tourist function development, i.e. communities where the high level of tourist attractiveness (TAI) is reflected in the level of development of the tourist function (TFI); 
- Category 2 (High-Low) - encompassing 15 communities with a high level of the tourist attractiveness (TAI) and a relatively low level of the tourist function development (TFI), i.e. municipalities whose tourist attractiveness has not yet become a prerequisite for proper development of tourist function;

- Category 3 (Low-High) - encompassing 10 communities with relatively low tourist attractiveness (TAI) and a developed tourist function (TFI), i.e. areas for which the tourist function is developed on the basis of factors other than natural or cultural attractiveness (especially those characterised by favorable location close to important urban centers or major transport routes);

- Category 4 (Low-Low) - encompassing 24 communities with a low level of tourist attractiveness and a low level of tourist function development.
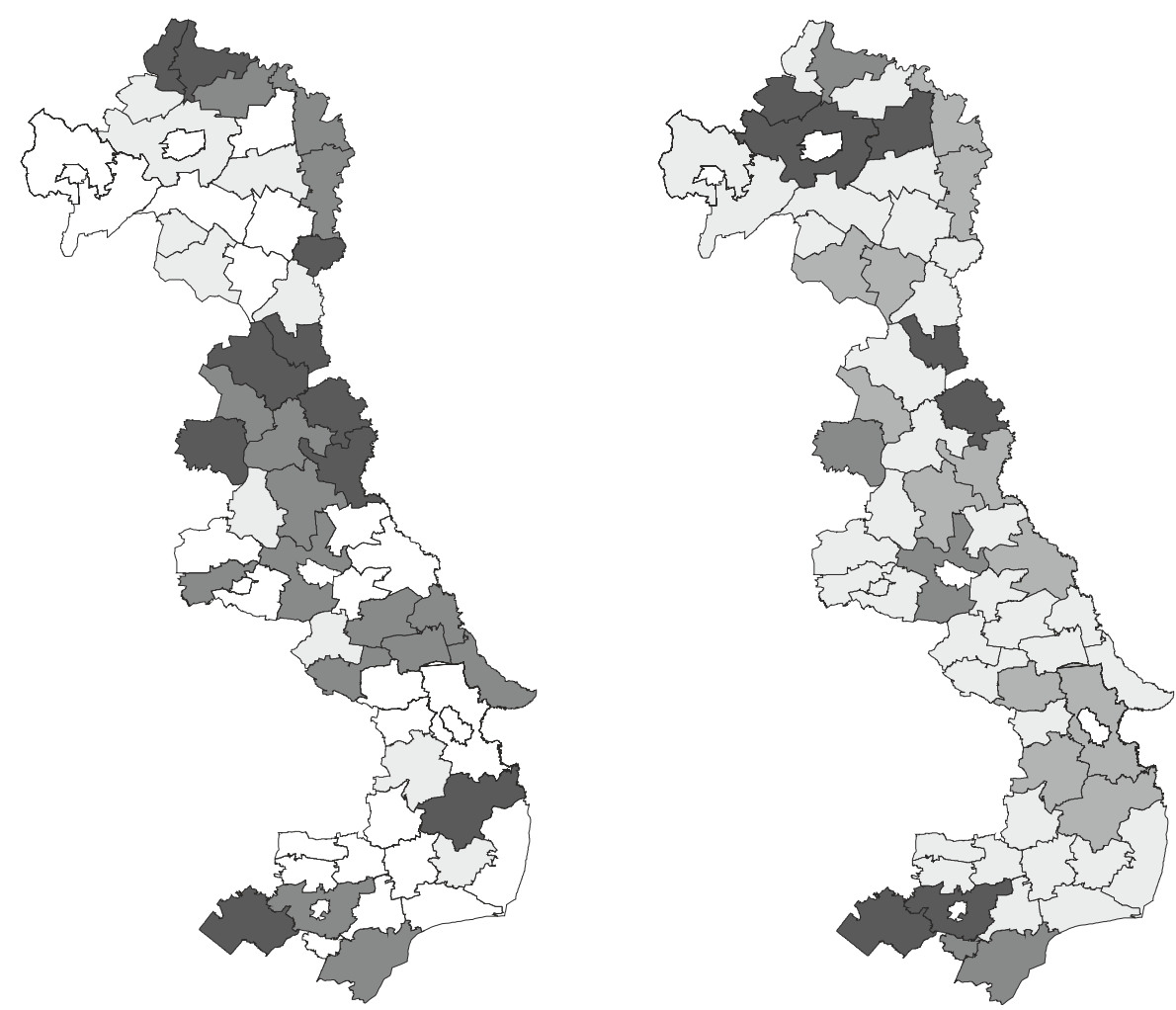

Tourist Traffic Index (TTI)

category $1(\mathrm{HH})$

category $2(\mathrm{HL})$

category $3(\mathrm{LH})$

category 4 (LL)

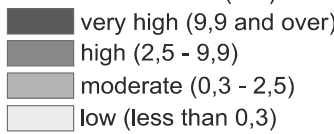

Fig. 3. Classification of communities according to terms of the utilisation of tourist attractiveness for the purposes of tourist function development and the spatial distribution of the Tourist Traffic Index (TTI).

Source: Authors' own elaboration. 
Areas qualified for Category 2 can be considered as the communities where the untapped potential for development of the tourist base exists, which is an essential condition to attract potential tourists. It is also worth emphasizing, that only 6 rural communities located on the border areas of the Lubelskie Voivodeship are characterised by very large tourist traffic (TTI) and only in two cases is this due to their very high tourist attractiveness (Fig. 3).

\section{Conclusions}

The problem of tourism potential in the Lubelskie voiodeship has been the subject of interest for much research (Brzezińska-Wójcik, Skowronek, 2009; Brzezińska-Wójcik, Świeca, Tucki, 2009; Krukowska, Świeca, 2009; Świeca, Brzezińska, Wójcik, 2009; Tucki 2008, 2009; Wesołowska, 2014). However, in their considerations they focused mainly on tourism performance, attractiveness, role and functional typology as well as prospects for tourism development in different spatial dimensions. They didn't pay any special attention to the border location and the rural character of the communities. The development of tourism stimulates many socio-economic changes. It is a chance for professional activation of the population, income generation or infrastructure development. Therefore, developing tourist functions of a given area is important for proper programming and the use of planning tools that allow for a coherent strategy that takes into account the activity of all tourism market operators, both in the private and public sectors. That is why rural tourism should be recognized by policy makers as an important economic strategy.

Considering the research results, it seems that the basic factor influencing the attractiveness of the border communities and at the same time creating conditions for the development of rural tourism is their natural values. Another finding is the observation that rural tourism is seen as an alternative, important factor of socio-economic development and as a supplementary economic sector in the northern part of the borderland, whereas in the southern part it is not perceived as a development priority mainly because of the favourable conditions for agricultural production.

\section{Literature}

Bezkowska, G. (2003). Problemy oceny walorów przyrodniczych dla turystyki rekreacji na obszarze Nizin Środkowopolskich. Turystyka i Hotelarstwo, 4, 9-33.

Briedenhann, J., Wickens, E. (2004). Tourism Routes as a tool for Local Economic Development of Rural Areas: vibrant hope or impossible dream? Tourism Management, 25, 71-79.

Brodziński, Z. 2011: Stymulowanie rozwoju obszarów wiejskich na poziomie lokalnym na przykładzie gmin województwa warmińsko-mazurskiego, Wyd. SGGW, Warszawa.

Bronisz, U., Dymek, Z., Jakubowski, A., Tucki, A. (2017). Potencjał turystyczny województwa lubelskiego w 2015 r., Urząd Statystyczny w Lublinie, Lublin.

Brzecińska-Wójcik, T., Skowronek, E. (2009). The tourism potential of Tomaszów Roztocze as exemplified by the urban-rural commune of Krasnobród. Annales UMCS, sectio B, 64(1), 171-199.

Brzezińska-Wójcik, T., Świeca, A, Tucki, A. (2009). Possibilities for development of tourism in Eastern Polish Voivodeship. Polish Journal of Sport and Tourism, 16(2), 65-84.

CODGiK (2017). Accessed 12 April 2017 from: http://www.codgik.gov.pl/index.php/darmowe-dane/nmt100.html.

Debniewska, M., Tkaczuk, M. (1997). Agroturystyka. Koszty, ceny, efekty. Poltext, Warszawa.

Drzewiecki, M. (2002), Podstawy agroturystyki, Bydgoszcz: Wydawnictwo OPO. 
Eurostat (2017). Degree of Urbanisation (DEGURBA) - Local Administrative Units. Accessed 13 July 2017 from: $\mathrm{http} / /$ ec.europa.eu/eurostat/ramon/miscellaneous/index.cfm?TargetUrl=DSP_DEGURBA.

Holland, J., Burian, M., Dixey, L. (2003). Tourism in Poor Rural Areas - Diversifying the product and expanding the benefits in rural Uganda and the Czech Republic, [in:] PPT Pro Poor Tourism Working Paper Series, No. 12. Accessed from: http://lib.icimod.org/record/11291/files/1408.pdf.

Krukowska R., Świeca A., 2008, The development of second homes as a form of using recreational areas for tourist purposes as exemplified by the Łęczna-Włodawa Lake District [in:] J. Wyrzykowski (ed.). Conditions of the foreign tourism development in Central and Eastern Europe. Tourism in geographical environment, 10, Wrocław, 175-184.

Lane, B. (1994). What is Rural Tourism. Journal of Sustainable Tourism, 2(1\&2): 7-21.

Łysoń, P., Szymkowiak, M., Wawrowski, Ł. (2016). Badania porównawcze atrakcyjności turystycznej powiatów z uwzględnieniem ich otoczenia. Wiadomości Statystyczne, Rok LXI, 12(667), 45-57.

Majewski, J. (1998). Turystyka wiejska - między rozwojem a ochrona dziedzictwa, [in:] Rozwój obszarów wiejskich w perspektywie integracji z Unią Europejską, Instytut Mikołaja Kopernika, Toruń.

Majewski, J., Lane, B. (2003). Turystyka wiejska i rozwój lokalny. Fundacja Edukacja dla Demokracji, Warszawa.

Rosner, A. (red.). (1999). Typologia wiejskich obszarów problemowych. IRWiR PAN, Warszawa.

Świeca, A., Brzezińska-Wójcik, T. (2009). The tourism resources and possibilities using of its for development of the town and commune of Nałeczów and the commune of Wojciechów. Annales UMCS, Lublin, sectio B, 64(1), 145-170.

Theodoropoulou, H., Kaldis, P. (2008). Changes in rural areas and regional development. Journal of Social Sciences, 4(4), 275-279. DOI: 10.3844/jssp.2008.275.279.

Tolstad, H.K. (2014). Development of rural-tourism experiences through networking: An example from Gudbrandsdalen, Norway. Norwegian Journal of Geography, 68(2), 111-120.

Tucki, A. (2006). Walory turystyczne Lubelszczyzny w świetle regionalizacji turystycznych Polski. Zeszyty Naukowe WSSP, 1, 133-140.

Tucki, A. (2008). Potencjał turystyczny regionu lubelskiego i możliwości jego wykorzystania. Maszynopis pracy doktorskiej, Lublin.

Tucki, A. (2009). Potencjał turystyczny regionu lubelskiego. Annales UMCS, sectio B, 64(1), 15-35.

UMWL (2015). Plan zagospodarowania przestrzennego województwa lubelskiego. Accessed 10 July 2017 from: https://umwl.bip.lubelskie.pl/index.php?id=935\&akcja=szczegoly\&p2=1036209.

Wesołowska, M. (2014). The development of tourism in rural areas in the Lubelskie Voivodeship. Studia Regionalia, 39, 247-260. 